Canadian University Music Review

Canadian University Music Review

Revue de musique des universités canadiennes

\title{
Musical Life in Eighteenth-Century Halifax
}

\section{Frederick A. Hall}

Numéro 4, 1983

URI : https://id.erudit.org/iderudit/1013907ar

DOI : https://doi.org/10.7202/1013907ar

Aller au sommaire du numéro

\section{Éditeur(s)}

Canadian University Music Society / Société de musique des universités canadiennes

\section{ISSN}

0710-0353 (imprimé)

2291-2436 (numérique)

Découvrir la revue

\section{Citer cet article}

Hall, F. A. (1983). Musical Life in Eighteenth-Century Halifax. Canadian University Music Review / Revue de musique des universités canadiennes, (4), 278-307. https://doi.org/10.7202/1013907ar

(c) Canadian University Music Society / Société de musique des universités canadiennes, 1983
Ce document est protégé par la loi sur le droit d'auteur. L'utilisation des services d'Érudit (y compris la reproduction) est assujettie à sa politique d'utilisation que vous pouvez consulter en ligne.

https://apropos.erudit.org/fr/usagers/politique-dutilisation/ 


\title{
MUSICAL LIFE IN EIGHTEENTH-CENTURY HALIFAX
}

\author{
Frederick A. Hall
}

When Captain William Moorsom wrote a series of letters from Nova Scotia in the early nineteenth century he presented a picture of a wilderness settlement lacking most of the cultural attributes of English society. The following statement sums up his and many other visitors' views of the cultural life of this area of Canada:

The exquisite powers of musical concert, and of all that has been so emphatically comprised ... under the term "Conversation" are here almost unknown, and, except in two or three solitary instances, hardly attempted (1830: 97).

The opinions of Moorsom and others to the contrary, the Canadian Maritime settlements did know about the "exquisite powers" of music and had produced in a very short time a musical life that formed an integral part of their social pastimes. ${ }^{1}$

When the British established Halifax in 1749 a new era in Maritime history began. The first year was spent in creating adequate fortifications to defend against Indian attacks which never materialized and in establishing a town outside the garrison walls. In a letter from Nova Scotia that appeared in the London Gentlemen's Magazine, the anonymous writer recorded this first year at Halifax:

When I look back upon the 21st June, the day of our arrival, I am astonished to see the progress made; there are already about 400 habitable houses within the fortifications and not less than 200 without. So surprising is the growth of this colony .... . 


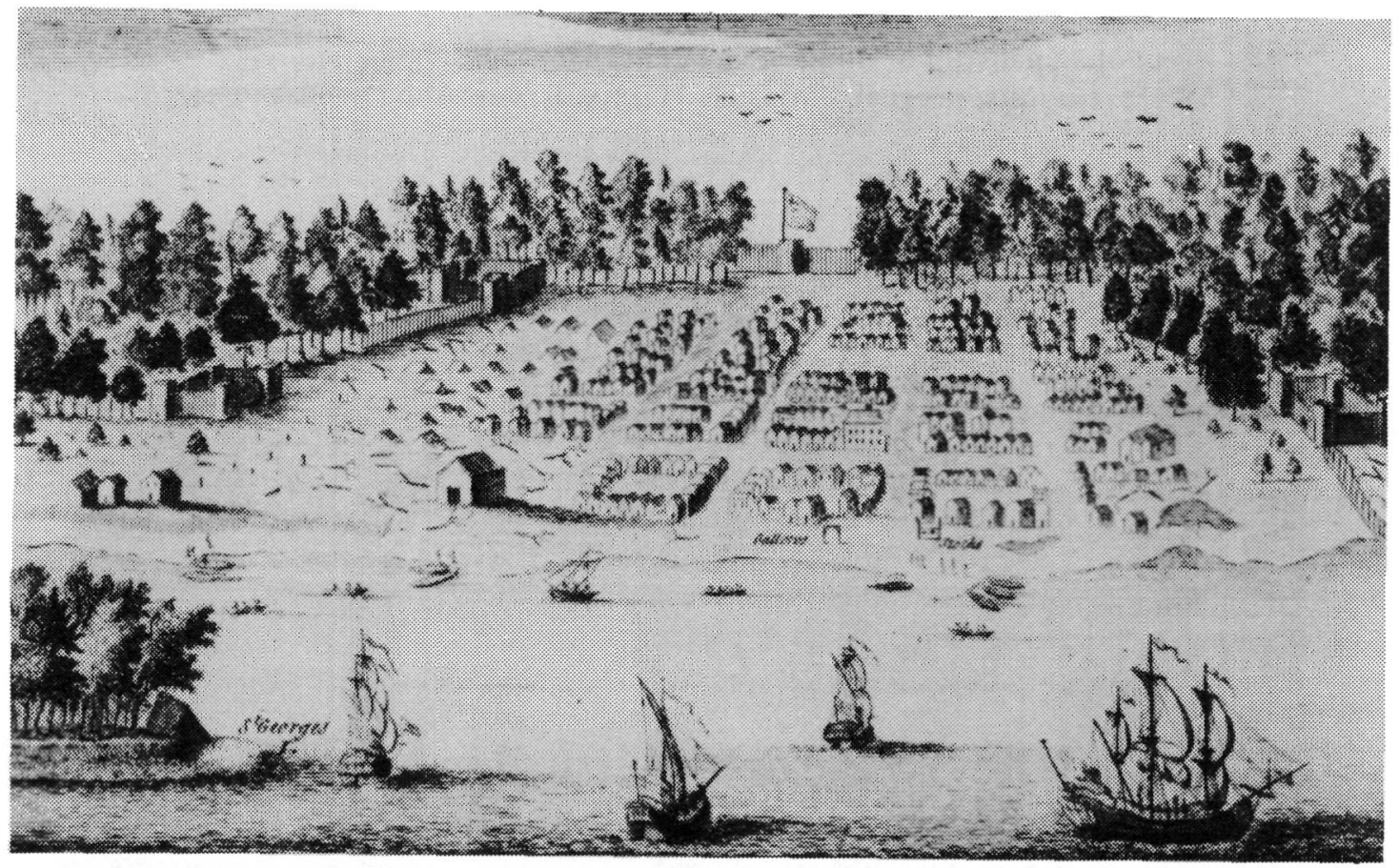

Figure 1

"Halifax drawn from ye topmasthead, 1750." Printed and published by T. Jefferys, London, 1760. 


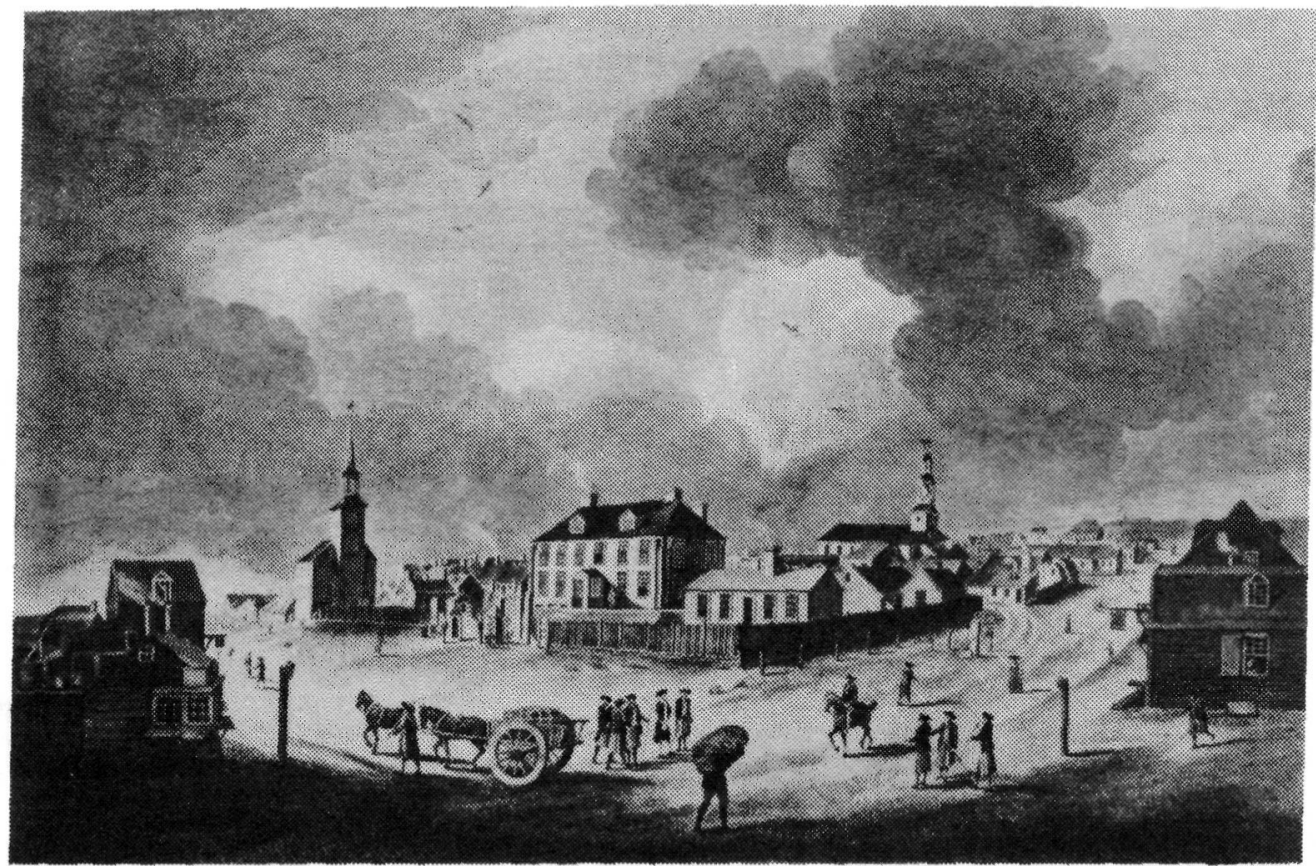

\section{Figure 2}

"Governor's house and St. Mather's meeting house at Halifax-1759." Painted by Serres from drawing by R. Short; published by John

Boydell, London, 1777. 
By 1755 a population of over 1,700 souls was recorded in a census. Throughout the 1750 s and 1760 s the town proper grew sporadically as large troop movements and migrations to inland settlements tended to cause fluctuations in the population. However, by 1769 five thousand people were settled in Halifax and a large commercial area on the waterfront and adjoining streets had been established. These businesses relied on supplies from Boston and several other southerly ports as well as regular shipments from England. The society that emerged during this period catered to the needs of frontier defences by providing goods to the troops and by growing some crops that could feed the town and garrison. A limited class structure was in evidence, with commanding officers of troops and their chosen civilian authorities controlling the town's legal and military affairs. Nevertheless, middle-class merchants, farmers, and laborers had no choice but to mingle in such a small settlement. Public social events were open to most townspeople for the price of admission.

It was a harsh system that imposed social order on this disparate group of settlers. Liquor offenders were punished with the lash and public stockade, housebreakers with execution, and counterfeiters, judging from the case of one Christopher Moore, sentenced to stand on the pillory for "one hour his ears to be nailed to the pillory and to be whipped ...." ${ }_{3}$

What role did music play during these formative years in struggling settlements established for defence and territorial occupation? From evidence in newspapers, letters, and other original documents, one can observe the gradual growth in the popularity of music in these volatile times. After survival was assured and the main elements of social order were in placehousing, legal authority, and adequate food supply-inhabitants sought forms of relaxation and entertainment to make the long winters more tolerable. Settlers undoubtedly brought small instruments and some music with them from their original homes. Dancing, singing in homes, taverns, and coffeehouses, and worship in churches constituted early musical activities in which all townspeople could participate.

Opportunistic merchants, seeing a potential market for music, were soon importing supplies for these aspiring musicians along with seeds, clothing, and farm implements. Within the first five years of the new settlement, the Halifax papers began to advertise music and instruments. Auctioneer William 


\title{
Imported frun: LONDON,
}

In:he Ship Diamord, Capt. Adamfon, and to be sold by $R$ O B E R T F L $:$ T C II L R,

\begin{abstract}
A Frefh Affortment of books, STATIONARY, and a few Articles of lewellr;; Ec. which he is letermined to fell on the luwest 'Terms for CASII only, ruz.
D ARCHMEA'T; Smpperfine Royal 1 is Demy Papar, Folio of Nuarlas Pyl, giit and pluin: bejt Foul's Cap $E$ Pot Puper, Gea-Puper, E'c. Ink Pow- der, licheri Liquid int-Giates, and Sand Bexesnef varicus Nirsd's bef Office Pens; S!idies E Sluse Pensils Midutte sn's black. Lead Pencils ; Folding Sricts ; Rid Tape

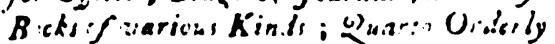

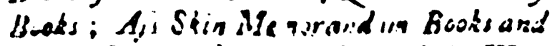

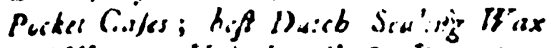 te. Al:o Lrindikips and l'aintings on and itich priats. for Oftices; Ledgers, Gourre:al, and Day.

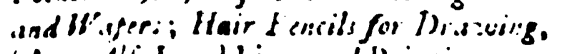

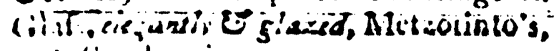

Gernmon Flutes and Vinlins

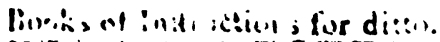

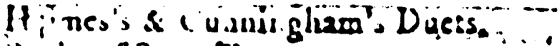
liooks of Scii I I'un's.

Real's, Snincile's, L ourdai's, se Berg's Duserg.

Figure 3

"Imported from London . . by Robert Fletcher." Nova Scotia Chronicle, 31 July-7 August 1770: [255]. 
Craft, in August of 1754, offered a songbook entitled Cupid, opera glasses, and two German flutes, plus fishing rods, gunpowder, muskets and a tobacco engine. ${ }^{4}$ Monsieur Cuenod, who stayed in Halifax for several years, regularly advertised "cheeses ...., yellow burnish'd nails for coffins ... . fiddle strings, and spare bows for violins . . . ." ${ }^{5}$ In 1769 Robert Fletcher, situated on the Parade in Halifax opposite the Governor's House, began to compete with Cuenod and listed books and stationery imported from London, including two song collections. ${ }^{6}$ One publication, The Chearful Songster, featured "songs, catches, and glees of mirth, jollity, hunting, and the bottle." Also, he offered London dramatic publications such as The Padlock, a play that had premiered in the English capital six months earlier and was to appear on Halifax stages two decades later. Fletcher obviously found a market for his musical wares, for a year later he sold German flutes and violins, books of musical instruction, various collections of instrumental duets, and music manuscript paperpossibly to supply those who wished to make arrangements of music for different instrumental combinations available in the settlement. ${ }^{7}$ Advertisements placed by three dealers in stiff competition with one another and with two auctioneers reveal that in the 1770s and early 1780s the following items were sold: a chamber organ, several pianofortes, violins, guitars, spinet strings, psalm and hymn books, numerous flute and violin instruction books, and vocal music collections, which included songs and airs from the current London operas. By 1791 Charles Geddes featured a complete line of violins, clarinets, German flutes and fifes, music instruction books, as well as harpsichord, spinet, pianoforte, and guitar strings and frets. ${ }^{8}$ Ships from Boston and London regularly listed musical supplies as part of their cargoes, and despite the tensions with the United States and the sinking and capturing of ships, it appears that dealers were able to secure an adequate supply of instruments and music.

What all this commercial activity indicates is that the dealers brought numerous instruments and books to the settlement and sold them to a public that apparently could entertain itself. In addition, the garrison contained many musical men who played in the bands and likely performed chamber music as a pastime. The number of replacement parts sold for keyboard and for stringed instruments shows that the instruments were actually played. 


\section{To be Is 0 L $D$ \\ By. GEORGE GRAVES \\ At bis Shop, on the lower the of the Parde oppofice ibe Churet. \\ Violins, Mufick Books and Mufick

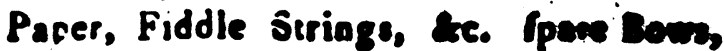 \\ French Olives, and Wallouts, Raifoas, Camanes, Fig. Prunes, Shell Almonda, beff ferdan Almoende,}

Figure 4

"To be sold by George Graves." Nova Scotia Gazette and Weekly Chronicle, 4 January 1780: [3].

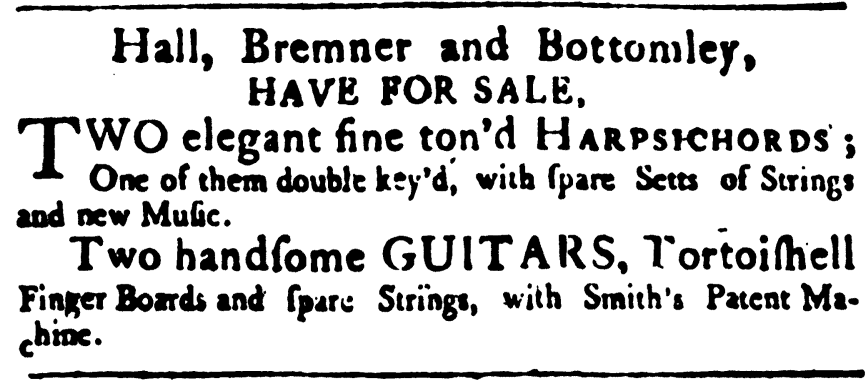

Figure 5

"Hall, Bremner and Bottomley ..." Royal Gazette and Nova Scotia Advertiser, 21 May 1793: [1].

A parallel development to this interest in selling instruments and music was the musical education of the settlement. Services offered by teachers indicate the musical skills available to the community. Gentlemen of the garrisons stationed in the Maritimes brought with them both their instruments and their musical talents. The regimental bands played for many military and social functions, and undoubtedly these same military men taught others during their long periods of waiting for military action. As early as 1761 , just twelve years after Halifax was founded, Halifax residents could study German flute, violin, French horn, oboe, and bassoon. ${ }^{9}$ Other enterprising military officers combined their social and military skills and offered tutelage in the "cut and thrust" of the small sword along with dancing lessons. ${ }^{10}$ 
AT the Academy in Grafton-Street, rourig Gentlemen

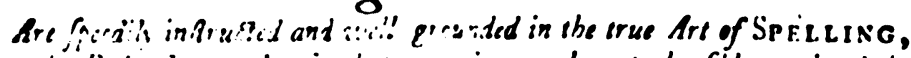

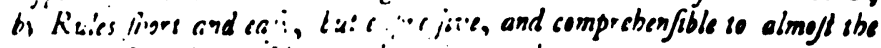

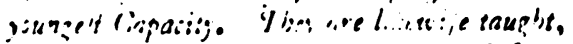

$\mathbf{R}$ Eading, Writing, Arithmetick, French,

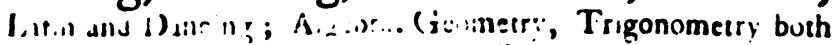

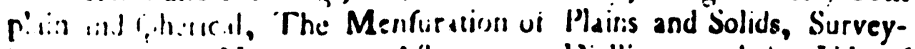

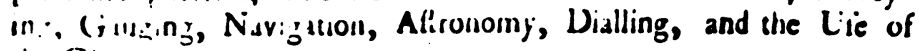

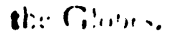

Ni: MATION and ASTRONOMY are taught either in the com-

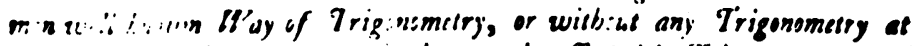

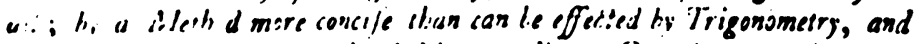

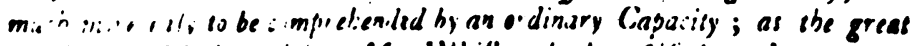
$n: 1:$, r.. 1 thethem.ticiun Mr. Whilton hath erfificd, ard as may be

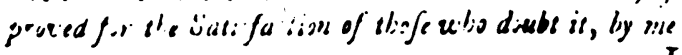

Finry Meriton.

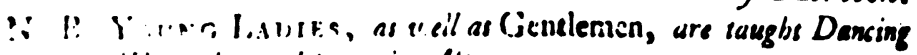

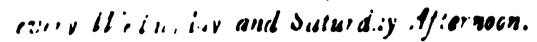

Figure 6

"At the Academy in Grafton Street ..." Halifax Gazette, 6 April 1752: [2].

Some individuals offered instruction in pianoforte, harpsichord, or spinet. The quality of such instruction is certainly open to question. A letter from Fredericton records some serious reservations about the abilities of two ladies who taught music in that town:

It is certainly a mistake that the Miss Mansons have come abroad as teachers of music; one of them plays the pianoforte a little, but I think cannot have had an idea of exalting herself into a teacher of scholars - they both sing rather well, scotch songs I think ... but their pronunciation is too barbarous to my ears .....11

In these years of development, music education, though sporadic and probably quite uneven in quality, provided the basis for a second generation of music making and for the great burst of musical activity in the closing decade of the eighteenth century. 
This is to give Notice to anz.. Gentlemen,"

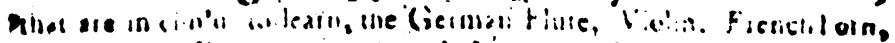
Hautbo:, B.jli:1 : : ins neher Inttringent ef lie like h.nd; may

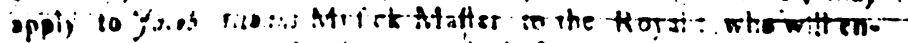

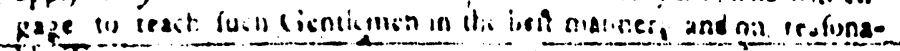
ble Trins.

Figure 7

"This is to give notice to any gentlemen ..." Halifax Gazette, 21 May 1761: [2].

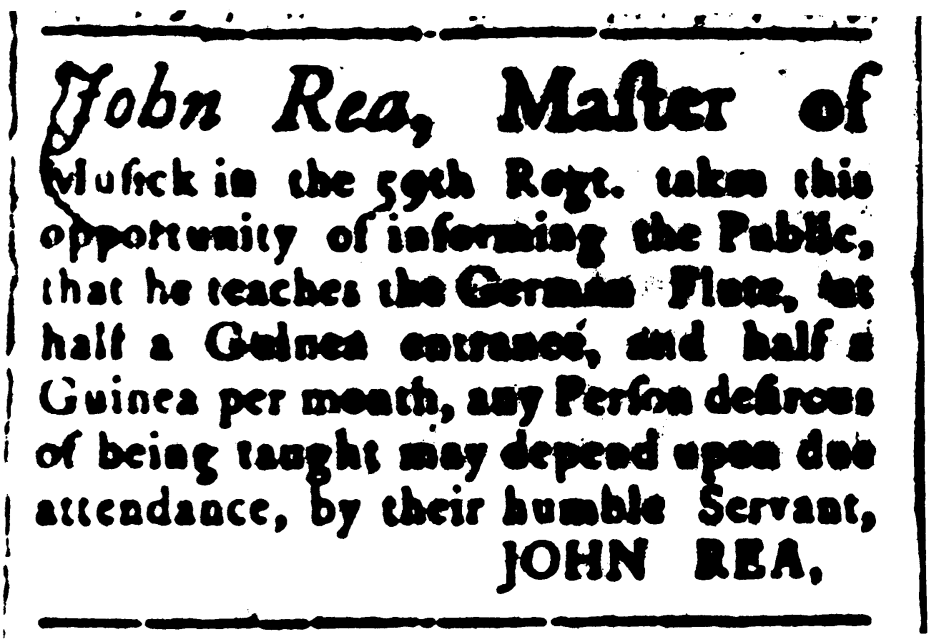

Figure 8

"John Rea..." Nova Scotia Gazette and Weekly Chronicle, 29 June 1773: [3].

The church was often a natural center for musical activity in a young community. Religious traditions were easily transferred to the settlement when a minister arrived with the troops. The establishment of St. Paul's Anglican Church in 1750, one year after Halifax's founding, ensured the church's presence in the community. St. Paul's was situated on the Grand Parade, and all ceremonial reviewing of troops took place in view of the building. As early as 1761 a letter to England records that the parishioners had been attempting for several years to purchase an organ for the church, although some Haligonians wanted instead to acquire a fire engine with the funds that had been collected! ${ }^{12}$ It was not until 1766 that the organ finally arrived and was installed. ${ }^{13}$ The Anglican tradition was probably dupli- 
cated through the use of standard hymnals, and the early services in all likelihood employed music in a limited way. The presence of a large congregation of dissenters in Halifax, which at first also used St. Paul's as a place of worship, and the influence of Loyalists affected the development of a varied musical liturgy. ${ }^{14}$ The Congregationalists and Presbyterians who settled in the Maritimes reinforced the conservative attitudes toward music, restricting their musical activities to the singing of the simpler psalms and hymns and resisting any use of instruments in their worship. These prevailing conservative attitudes delayed the use of St. Paul's for public concerts, but by 1789 a large musical concert as part of a service was announced in the newspaper. In celebration of King George III's recovery from insanity, the final chorus of Handel's Messiah and one of his Coronation Anthems were performed by "several gentlemen and the music bands of the regiments" with organ. ${ }^{15}$ Similar religious concerts, however, seem to have been rare in eighteenth-century Halifax and if performed received no public notice.

Although sacred music made limited headway in the churches, secular music was promoted by the inns, coffeehouses, and taverns. These establishments catered to a wide cross-section of the population and offered a great variety of services to attract patrons. John Willis, an early innkeeper, announced the following improvements to his establishment:

Gentlemen of every profession, both of town and country, may rely on being genteely entertained at the most reasonable rates. He also purposes keeping a Chop-House, where Gentlemen may be supplied with the greatest dispatch, and dinners dressed at the shortest notice.

He begs leave to inform the Ladies, that he has a good convenience for baking .... and hot mutton pyes every day ....

He also begs leave to inform the public, that he has a huge and commodious assembly room ....16

Willis's assembly room and those of other inns were the main meeting places in Maritime towns. As early as 1751 a coffeehouse had been opened in Halifax and was soon followed by a succession of similar places. The Golden Ball Tavern, Sutherland's Coffee House, and the British Tavern were just a few of the establishments to offer libation, accommodation, and entertainment. 
One of the best known was the Great Pontac Inn erected by John Butler in 1754. It was the location of all major political ceremonies, such as the swearing-in of the Chief Justice, as well as large social entertainments. Elaborate balls and suppers were given by officers of the garrison and by the upper class of the town. One of the most lavish of these dinners was given by General Wolfe in $\mathbf{1 7 5 8}$ prior to his departure for Louisbourg. John Willis sent him a bill for this modest dinner and entertainment for forty-seven people. Dinners were served plus seventy bottles of Madeira, fifty bottles of claret, and twentyfive bottles of brandy. In addition, the services of ten musicians and fifteen special attendants produced a total bill of nearly one hundred pounds. What the musicians played, or if the revellers heard anything of this concert, is not recorded (see MacDonald 1912). ${ }^{17}$

The audiences attending early entertainments were probably less than attentive and more than impolite. Although few comments survive about concert decorum, a letter to the Halifax Gazette objected to the poor manners of even church congregations:

It is a common observation, that many who are called people of great sense do sometimes strangely deviate from that rectitude.... What brings this remark at present forcibly to my recollection is the want of decorum which is to be seen in places allotted and set apart by the community for the worship of the author of nature .... The beautiful, the gentle part of the creation convert the place ... into a scene of levity, whispering, and tittering ....

But the most inexcusable offenders against church decorum are those who not content with showing a total inattention to public worship make it impossible for others to engage seriously in it-among these are snuff-takers; this induces coughing, which in general no pains is taken to smother, but the reverse. Such as fall asleep and sometimes snore to the great amusement of some part of the congregation, such as talk so loud and constant as to be overheard by their neighbours, ... such as bring their dogs with them, a nuisance on all occasions, . . . and all such as resort to the place of heavenly contemplation merely to see and be seen .... ${ }^{18}$

If there was such a want of decorum within the house of God, the lack of manners in a tavern can only be imagined. Some 
indications of the unruly performing conditions encountered by musicians were given by Joseph Howe in a colorful review of a Halifax concert:

\begin{abstract}
Mr. Keene gave his first concert on Monday evening, and were we to judge by the peals of applause which followed every song, we might say gave very general satisfaction .... His next concert will be on Friday, when the votaries of music will again have an opportunity of enjoying an entertainment so rational, so innocent, and at the same time, so delightful.

We would suggest to our magistrates, and police officers, the propriety of keeping peace and decorum in the streets adjoining the lodge on the next evening; because the performance on Monday was repeatedly interrupted by all kinds of discordant noises; and several persons effected an entrance to the hall through the back windows, and others threw dirt and offal in, to the great annoyance both of the singer and the audience. This is not as it should be-what are public officers for if tranquility is not to be preserved? ${ }^{19}$
\end{abstract}

Maritime inns were interested in any type of unusual attraction that would entice customers to their premises. Seacord's Tavern offered its patrons "The Celebrated Learned Pig," which could tell time, distinguish colors, add, subtract, multiply, divide, and perform amazing card tricks. ${ }^{20}$ Many other entertainments featured actors, jugglers, and magicians who occasionally used music as part of their acts.

As certain taverns became well established with their clientele, their assembly rooms became the locations for much informal music making and some formal concerts which, by the early 1790s, matched in interest anything offered in the British territories. The repertoire utilized in these concerts consisted mainly of works written by eighteenth-century composers who already enjoyed popularity in the major European cities. Johann Christian Bach (1735-82), Giovanni Giornovichi (ca.1745-1804), Adalbert Gyrowetz (1763-1850), Antonín Kammel (1730-87), and Franz Kotzwara (ca.1750-91) appeared in London performances, especially the Hanover Square Series and the Ancient Concerts. Giornovichi, Rodolphe Kreutzer (1766-1831), and Étienne Solère (1753-1817) had works performed at the Concerts Spirituels in Paris. The third main category of composers were men active in Vienna and Mannheim and certainly well known to Parisian and London audiences. Such composers as 
By l'erminition of His Excelleang the Geverner.

To-Morrow Evening,

THz eqh INSTANT.

Will be performed, at the Correz-Hoosz,

A CON CERT

01

$I^{\prime}{ }^{\prime} \mathrm{u} a l$ and Inftrumental Mufic.

I.i THaER ACTS.

As in.

OVERTIIRE, compoleJ by TOESCHI. UU.RIEI TU. UIII BAVAUX.

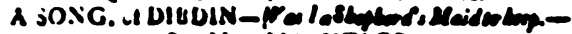
Ay Mon. Mechtice.

OVt:MIUAP. campold by BACH.

rodof ols of 19.

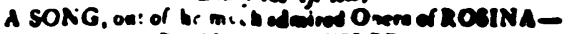
B) Mis. MECHTLER.

OVERT URE, compoled by MEBES.

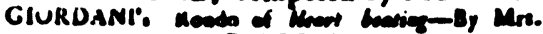
Mechther.

QUARTETTO, of AVESONS. encos ed.

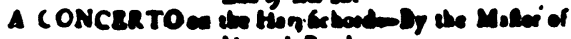
its rasis Band.

(1) 8 .

OVERTURR b ABEL.

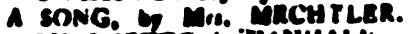
ounitritra ivanHall.

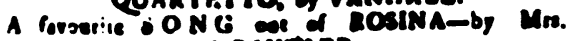
macitriza.

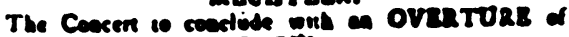
AnC:Pa.

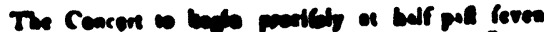

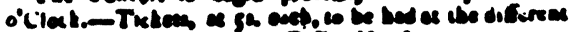

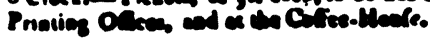

Figure 9

"A concert of vocal and instrumental music..." Royal Gazette and Nova Scotia Advertiser, 28 September 1790: [3]. 


\section{A CONCER T This Evenisg. At the BRITISH-TAVERN.} The fullowing favourite Pieces of MIUSIC, will be Perif. A Grand Overture Curmed? gd. I favouriti Quarirll By H.IYD. . ad. $\Lambda$ Du. Syenphosiy Hirir. fih. A Trio

$\therefore$ h. An Userfure

H.IYDN.

6iti. A misch adiuired Quaseell

:... A Trio KiIr WARA.

8ih. An ()verture K.1 $: 1,1 \leq 11$. git. A favousite Quarsell - Pisyil. 20:h. An Overture D、iA $\because x$. Pi zY Y L. Bich. The C(DNCERT begins at Siven o'Clork. TICKETS Price $1 \int 6$; to be liad of the Primer and at M. Gallagher's.

Figure 10

"A concert at the British Tavern ..." Royal Gazette and Nova Scotia Advertiser, 15 January 1793: [3].

Joseph Schmittbaur (1718-1809), Carl Toeschi (1731-88), and Johann Vanhal (1739-1813) typified the competent orchestral performer who also composed effective utilitarian music for orchestra. All these composers' works were also performed regularly in American cities such as Philadelphia, New York, and Boston.

The surviving Halifax newspapers of the period 1790-1800 list fairly specific details for ten concerts of instrumental music which presented the typical variety expected by eighteenthcentury audiences. Orchestral overtures, concertos, and symphonies regularly alternated with miscellaneous vocal and chamber works. The result is that Halifax musicians managed to present in just ten concerts during this decade of musical activity no less than seventeen different overtures, ten concertos, sixteen symphonies, and fifteen miscellaneous chamber works (quartets, trios, etc.). What has been difficult to determine, owing to a dearth of specific references, is what instrumental groupings were required to perform these works and what instrumentalists were actually available in Halifax. 


\section{At the Corter-Huse;}

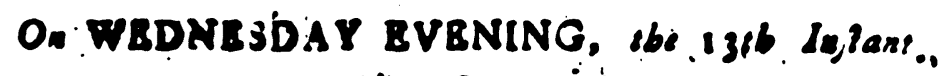
Will be Perforinge

A GRAND CONLER $\Gamma$

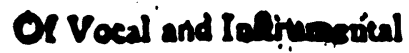

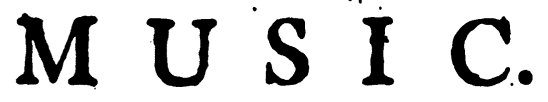

Confling of the followieg favourite Picesen; divided itwo ive

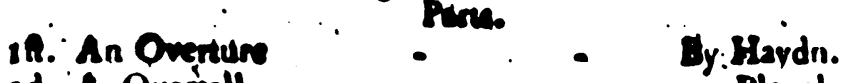
ed. A Quariell - - Plevel. 3d. An Air Hayed on the Spicaso - By Mr: Sihi ifero qith. A Sodot, Comfort ye ay People - Handel: sth: A guaratl . Dat.inx. Gh. A symptouy t - Varbal. Th. An Overtore , Haydena. 8h. A Song i why do the Nations - Mandel. git. A Quaruen - - Pleyel. Ioch. A Sympbony - - Sermiz. IIth. A Soop Hadel. isth. Tive Qverture of Heary sthe ith with Reule Dives and Truapere

N. B. The CONCERT, will be affifted, ty feveral Gemiaaen $;$ who perforns for thei! amulemeut.

Tickew mas he had of Mr. MINNS's, and \& the Colfies, Howfe. Price es. 64:

The CONCERT, begins pratiely $\approx 7$ o'Cleck. ssch March ?793.

Figure 11

"A grand concert of vocal and instrumental music ..." Royal Gazette and Nova Scotia Advertiser, 12 March 1793: [3]. 


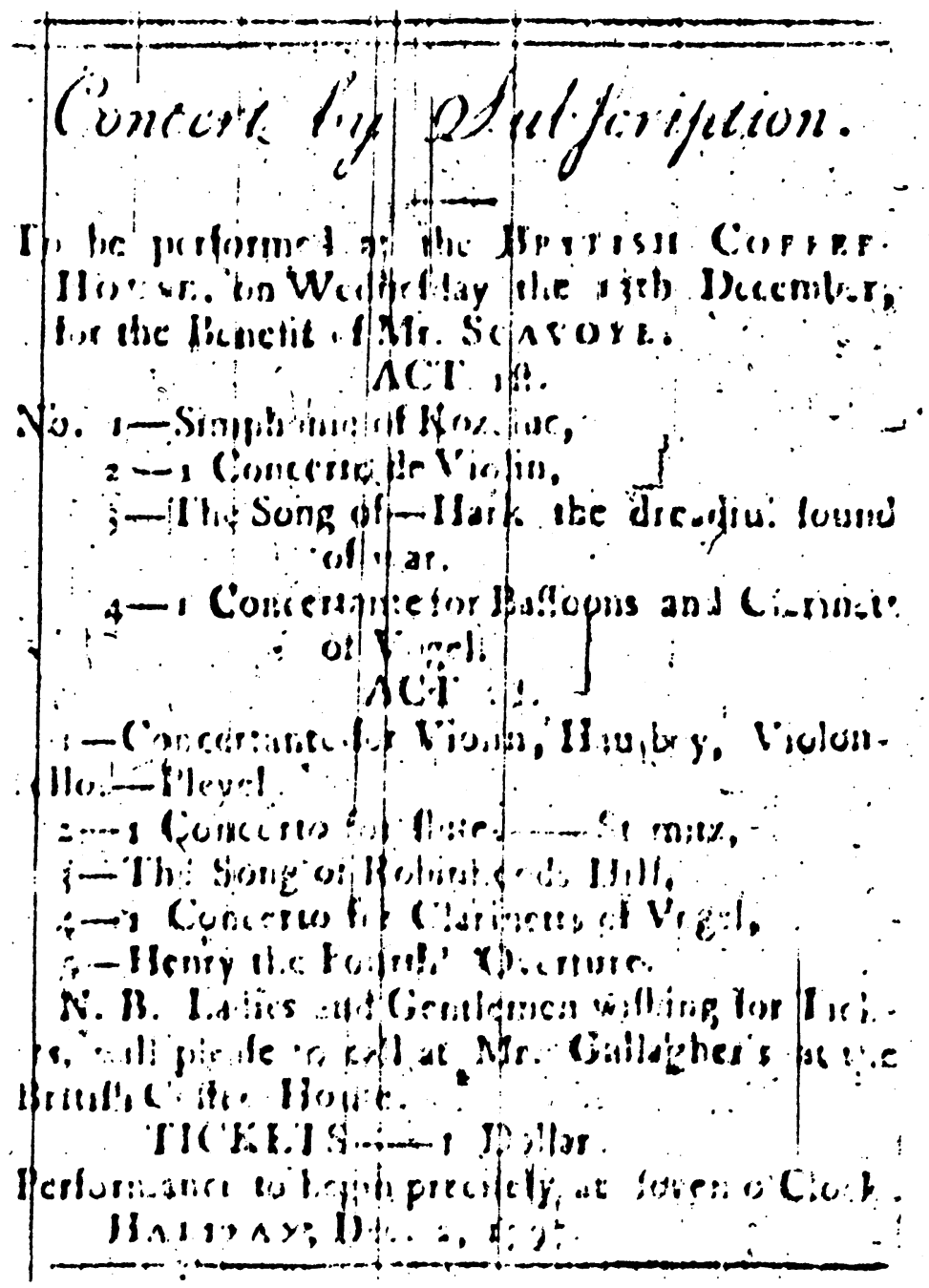

Figure 12

"Concert by subscription ..." Royal Gazette and Nova Scotia Advertiser, 5 December 1797: [3]. 
Works such as the overtures by J. C. Bach and Antonin Kammel and the symphonies by Leopold Koželuch (1747-1818), Johann W. A. Stamitz (1717-57), and Johann Vanhal require a minimum standard orchestra of the period; that is, many of these symphonies and overtures are scored for eight instrumental lines, four of them strings-two violins, viola, and cello with optional harpsichord-the remaining four parts constituting paired oboes or flutes and French horns. The occasional variants of this standard orchestra substitute clarinets for oboes and add an extra line for trumpet or bassoon.

The question of whether Halifax residents and garrison band members could have performed these works in complete form cannot be answered definitively because no lists of concert performers survive. However, the fact that Halifax dealers had sold many wind and string instruments to the community and that instruction was available for at least flute, violin, French horn, oboe, and bassoon, indicates that a suitable variety of instrumentalists was resident in Halifax. If the regiments stationed at the garrison had a minimal complement of musicians, they, along with the town musicians, could have performed the works listed in concert notices.

When Prince Edward Augustus (later the Duke of Kent) arrived at Halifax in 1794, after being stationed in Quebec with his band, the Royal Fusiliers, he provided further impetus to the burgeoning musical life. Edward loved music and had arranged for his band to perform at numerous entertainments in Quebec between 1791 and 1794. His patronage and genuine interest in music ensured an exciting musical life for the Maritime town during his stay. In some letters written to England between September 1794 and May 1800 Edward discussed his band. One particular letter dated 27 October 1795 is important for establishing some facts about the personnel and size of Edward's band:

I have written to a man at Brunswick of the name of Bies who served under me before in the Band of the Guards at Hanover, when I was their Colonel, to engage for me for a term of not less than six, and if possible of eight years, a complete band of tricolor, the first and principal condition being that none of them have ever served in France, or have the least appearance of harbouring French principles .... ${ }^{21}$ 
In the same letter he also gave authorization to spend seventytwo pounds to procure a maximum of twelve musicians from Hanover and Brunswick to form "a complete band of tricolor." One can conclude from the evidence found in the surviving letters that Edward maintained a band numbering twelve to sixteen musicians that included flutes, fifes, clarinets, trumpets, bassoons, sackbuts, and a drummer. Another important fact that emerges from Edward's military correspondence is that at least three other regiments stationed in the Maritimes had bands from which Edward recruited additional musicians. Therefore, Halifax apparently had a constant supply of military and civilian musicians for various concerts and operatic productions.

The British Coffee House featured Edward's band and local musicians in a series of concerts. For example, in December 1797, for the benefit of Mr. Scavoye, Edward's director of music and clarinetist, one concert featured a symphony by Kozeluch, concertos for solo violin, flute, and clarinet, and a concertante work for bassoons and clarinet. These pieces must have featured Edward's musicians as soloists and as members of the orchestra. Some bandsmen when playing indoors could switch to stringed instruments, and townspeople likely also contributed their skills. A month later, a benefit for Mr. Duplessy, who had been in Quebec with Edward, included some of the same concertos, but added a horn concerto and a "symphony concertante" for two violins. The concertante works programmed for these and other concerts were ideal for regimental bandsmen. Several different instruments could be featured and the individual solo roles were not too demanding.

With Halifax's population being increased by large troop concentrations, sometimes numbering as high as seven thousand, the morals of the town were strained to their limits. The troops came to the town for their entertainment and, although some patronized the better taverns, many soldiers frequented the upper streets, which became full of brothels. "Grog shops and dancing houses were to be found in almost every part of the town" (Akins 1895: 158). What these places offered for musical entertainment cannot be discovered as the very existence of these services for the garrison troops could not be acknowledged by the officers or officials of the town. However, letters to the editor bemoaned the low morals of the community and often blamed the early theaters for contributing to such debauch- 
ery. A letter in a Halifax newspaper summed up the moral outrage and climate of opinion in 1770:

Enter not therefore into the playhouse; it's the palace of Asmodeus, the seat of lewdness, the nursery of debauchery; ... a Christian cannot with a safer conscience enter into the playhouse than into a brothel; as things are managed there, temptation is stronger on the stage and more inviting, the blackness of the vice is under a disguise ...; the stage not only removes fear of punishment, but even rewards debauchery, for who are they that carry off applause and fortunes but rakes and prostitutes....22

Despite these negative views of the theater, often expressed by the United Empire Loyalists who had moved to Nova Scotia to protect their loyalty to England and uphold a religious doctrine, theaters gained popularity as soon as they appeared in the 1760s. British officers garrisoned in America at Charleston, Boston, New York, and Philadelphia had attempted to create a theatrical life. As a result, the latest London plays found their way onto American stages within a short time, and when British regiments and loyalist civilians left the United States after the Treaty of Paris in 1783, they imported their tastes along with their material possessions. In the 1780 s and 1790 s, as conflicts continued in Europe and tensions increased on the United StatesBritish North American border, the garrison at Halifax was strengthened with additional regiments to defend the Maritime coastline. Although much of their time was taken up with military concerns, the British regiments, in cooperation with the townspeople, did create social diversions. Regular advertisements in the newspapers of plays to be presented indicated their desire to produce their own entertainments.

These theater buffs did not produce original plays written in Canada, but instead attempted to reproduce the types of entertainments currently popular on London stages. While on leave, military men often attended the London theaters in Covent Garden and Drury Lane where an evening's entertainment consisted of two plays-the main production, normally two to five acts long, and a shorter afterpiece of one or two acts. Between the two plays musical entertainment might be presented, and of course some plays integrated musical numbers into the performance. Something of the character of these early Halifax productions can be gleaned from an 
advertisement announcing that officers of the garrison and fleet and two young boys of the town would present the plays The Guardian and The Lying Valet at the Great Pontac Inn. ${ }^{23}$ Between the dramas they promised a performance of "a favourite hunting song." In 1789 theatrical productions moved out of the Great Pontac and into a building which the officers of the garrison and gentlemen of the town constructed. William Dyott in his diary entry for February 1789 notes that "it was as complete a thing for the size as I ever saw, boxes and a first and second pit" (see Jeffery 1907: 61). Eight programs consisting of eleven dramas and farces were produced in the first year of operation.

Although plays were the most common productions done by the Halifax theater, thirty-seven musical-dramatic performances were given on the Halifax stage in the last decade of the eighteenth century. Surprisingly, there is no mention of a performance of The Beggar's Opera, but three other ballad operas, The Devil To Pay, The Ladies Frolic, and The Poor Soldier were presented in Halifax. These typical ballad operas contained mostly simple, strophic songs of a popular nature which were not difficult to perform because of their tunefulness and narrow melodic ranges. There is record of only one pantomime being presented. Robinson Crusoe by Thomas Linley was performed in August 1798 and repeated in January 1800. This pantomime deals with the Crusoe story and his rescue of Friday from the "savages." Without dialogue or sung texts, the actors mimed the story to almost continuous music; over thirty comic tunes are used in Act I alone. Ballad operas and pantomimes, however, formed only a small part of the entertainments presented between 1791 and 1800 . The main type was the comic opera which was the current popular entertainment in London. Modern writers often categorize these works as "ballad operas," implying that they were in The Beggar's Opera tradition and of similar content and musical difficulty. This in fact is not the case. These operas were products of the latter part of the eighteenth century, at least two decades after the ballad opera craze had begun to wane. Drury Lane, Covent Garden, and the Little Theatre in the Haymarket featured comic operas as part of an evening's entertainment, often combining the opera with a play. ${ }^{24}$ With the premiere of Love in a Village at Covent Garden in 1762, the new genre that emerged did not rely on popular songs and ballads, but featured art music, either borrowed from other 
HALIFAX THEATRE. For the Bewefit of the Poor.

On Thursday Erenixc next, the 7th Inft-

(Being for the lat Time this Searon) rilly ste prefonted

The Comic-Opern of

LOVE in $A$ VILLAGE.

To wbich will be added.

4 FARCE CALLLD

THB ADVENTURERS.

Between the Play and the Parce, fill be an Iulias Dance, Called La FRTĆANDOL,

Ai done a AILE Y'a Amphitheatre in L.ONDON.

A FAREWELIL EPILOGUE will be fpoken by one of the Managers.

Great care will be when to bave the Theatre comfortalle in every Rerper.

Thi Doors to he opperied at SIX, and the Performance to begin precifily at SEVEN o'Clock.

BOX 35 - FIRST PIT $3 .-S E C O N D$ PIT $\&$.

- Two Rows in the Firft Jitt will be raild in as Boxes; to accrommndate thufe $L$ adies and Gentlemen who have hitherio been difappointed-they will fend for Places and Tiskets accordingiy. - And to prevent any inconvenience in the Fird Pit, an additional Row will be taken into that from the Siecond Pit. .

TICKETS to be bad, and Places taken in the Boxes, aMr. MINNS's.

Figure 13

"Halifax Theatre ... Love in a Village ..." Royal Gazette and Nova Scotia Advertiser, 5 March 1793: [3]. 
operas, as in the case of pasticcio compilations, or newly composed music in a variety of styles from simple air to complex aria. The comic opera retained spoken dialogue in place of recitative, and the dramatic content reflected the styles currently in fashion in the playhouses. London audiences loved this type of entertainment and soon comic operas rivalled current London plays in popularity. ${ }^{25}$

Halifax, of course, could not match the number or variety of productions in London, or even in American cities. However, the city during the closing decade of the eighteenth century saw the performances of at least sixteen different comic operas, many of them still popular on the London stages, several having been premiered less than a decade earlier. The comic operas included such London favorites as No Song No Supper, one of the most successful afterpieces of the 1790s, which was presented in Halifax eight years after its Drury Lane premiere; Charles Dibdin's The Padlock, a sensational success of the 1760s which remained popular for over fifty years; the fulllength opera, The Castle of Andalusia, which anticipated early Romantic opera with its gloomy Gothic setting and noble hero disguised as a bandit (see Fiske 1973: 454); and Thomas Linley's and Richard Sheridan's Duenna, which in its first year alone was performed seventy-five times in Covent Garden. As with the instrumental concerts, the question arises again regarding operatic performances; that is, could the soldiers and civilians of Halifax produce operas and dramas with proper sets, costumes, singers, actors, actresses, and instrumentalists? There is no definitive answer, but it seems likely that these productions were adequate. William Dyott went so far as to say, after attending a performance of the School for Scandal, that he "never saw a play better performed out of London" (see Jeffery 1907: $60)$. A year later, during the first season in the new theater, he stated that "the plays were very entertaining, as some of the characters were vastly well supported" (see ibid.: 61). Because Dyott was the treasurer for the theatrical productions, he might have been overly enthusiastic and only too willing to overlook deficiencies.

If the requirements for presenting comic operas are examined, we might be better able to judge the quality of Halifax productions. The stage sets were similar to scenery required for dramas and because the officers were able to build a complete theater, it seems likely that skilled craftsmen could construct 


\section{HALIFAX THIZ:.ATR!:

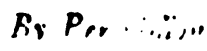 \\ TUIS liVENINGi, tie a iatr.

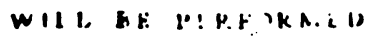 \\ An Attic Iintertilimasent,}

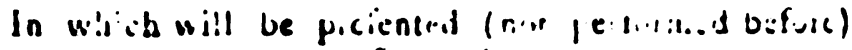

Sienc lioull

The Poor Solcilit;

Between D) rivy a: : Purick.

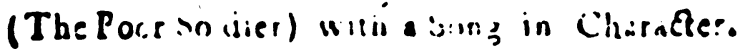

'IIIne Padlocls,

In which will be in'roduced, the ( harafiera of

Don Dicyo, Leonori, liffula, Leander, and Mun! g.!').

With PROLOCUE, alid k.ill.', , liji:S

The whole to corciude wi:a

The Shooting of Harlequin.

Doors to te opened a: $j$, and io brein a. 6 sicic: politively.

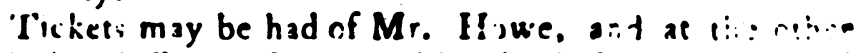

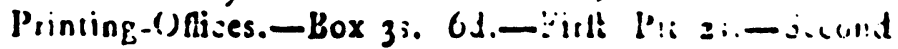
Pit I. 3.

Figure 14

"Halifax Theatre ... The Poor Soldier ..." Royal Gazette and Nova Scotia Advertiser, 4 January 1791: [3]. 
adequate scenery for the stage. The spoken parts of the comic operas posed no problems because they could have been assigned to actors who had gained experience in local theatrical productions. The musical accompaniment was easily adapted to match the instrumental resources available in the community. Since orchestral scores were unavailable, musicians used published piano reductions which in some cases gave indications of instrumentation. For example, the published score of the overture to Rosina, presented in Halifax in 1795 , contains indications in the piano score for entries of clarinet, horn, and bassoon. The director of music in Halifax, Mr. Scavoye, using the piano score, easily could have written out separate instrumental parts for the musicians. This method was common eighteenth-century practice, as was the substitution or even deletion of some instruments. Certainly the Halifax regimental bands, which presented the varied instrumental concerts of the period, could have performed the instrumental overtures and accompaniments of these comic operas.

The operas required at least two skilled singers who had to perform songs ranging from lyrical airs to difficult ornamented arias. Rosina, which was based on a libretto by Frances Brooke, is an afterpiece containing no large-scale arias but requires rather a singer who can perform simpler melodic airs. In contrast, the airs in Love in a Village, composed by Arne, contain long melismatic passages covering a wide vocal range, and No Song No Supper includes challenging airs for singer and obbligato instruments.

Very little evidence survives that can shed light on who performed the singing roles in Halifax productions. Most advertisements for complete performances of plays and operas do not list the names of the performers. Singers probably were not identified because it was still not socially acceptable for women in particular to appear on the stage. Halifax was still a conservative community, and the wives of officers, who were often the daughters of established British families, and talented women of the town appeared on the stage with no public fanfare that would suggest impropriety.

We do know that Mr. Powell, who provided musical entertainments in Halifax, could sing, and that his daughter Cordelia sang an air from Rosina in a vocal and instrumental concert. The most skilled singer might have been Mrs. Mechtler, who appeared in several concerts singing excerpts from operas. Her 
maiden name was Fanny Storer. Both she and her sister had performed in the United States, and Fanny, after marrying $\mathrm{Mr}$. Mechtler, toured with her husband and stayed in Halifax for a period. In a benefit concert for her in July 1791, she and her husband performed vocal works, including an excerpt from The Padlock, which had been presented in a staged performance the previous month. Undoubtedly Mrs. Mechtler performed the leading role of Leonora in this production.

Who attended the theater? Certainly the officers from the garrison and appointed town officials were expected to patronize such ventures and probably they purchased most of the box seating. However, there was not an aristocracy or even what legitimately could be called a landed upper class in Halifax. The social demarkations were much less precise and probably the merchant class, the privateers, and other men of means purchased seats. In addition, the second pit probably contained servants who had driven their masters to the play. Therefore the theater did have what accurately could be called "popular support." In fact, demand was so great that additional boxes were constructed and other major alterations undertaken to satisfy patrons.

Music during this period of growth in the Maritimes enjoyed a special status from the outset. It can be argued that the music performed in Halifax was simply a poor copy of the London musical scene. On the other hand, it can also be stated that in less than fifty years this struggling garrison and trading town was able to establish a society that was musically sophisticated. Within a few years of the London premieres, Halifax theaters mounted the same plays and comic operas. Their concert seasons could not compare to the British ones, to be sure, but the beginnings of chamber groups, orchestras, and choirs were in evidence, and by the mid-nineteenth century these efforts resulted in newly-formed choral and philharmonic societies.

The lack of an aristocracy and established patronage system guaranteed that most people could participate as performers or listeners. Any musically talented person, whether a British officer or soldier, assemblyman or merchant, could have participated in concerts or plays in the theaters, taverns, and coffeehouses of this British colonial outpost. Unquestionably, Halifax had been successful in producing in a very short time a musical life that formed an integral part of the settlement's social pastimes. 
OPERA PERFORMANCES IN HALIFAX 1791-1800 $\dagger$

\section{Halifax}

Performance

Date

Jan. 1791

Feb. 1791

May 1791

June 1791

Jan. 1793

March 1793

Jan. 1795

Jan. 1795

[2nd. perf.

July]

March 1795

April 1795

Feb. 1796

[2nd. perf. March]

\section{Title}

The Poor Soldier (one scene)

The Padlock (4 scenes)

[see below]

The Rival Candidates

The Devil to Pay

The Padlock

Duenna

Love in a Village

The Poor Soldier

Agreeable Surprise

Rosina

The Poor Soldier

[see above]

The Castle

of Andalusia
Composer

Thomas Carter

Cibber,

Rochester, and others

Charles Dibdin

Thomas Linley

Sr. and Jr.

Pasticcio compiled

by T. Arne

Pasticcio-O'Keeffe

and Shield

S. Arnold

Wm. Shield

Pasticcio

compiled by S. Arnold

\section{Author}

Type

Henry Bate (Dudley) Comic Opera

2 acts

C. Coffey and

J. Mottley

Isaac Bickerstaff

R. Sheridan

I. Bickerstaff

John O'Keeffe

J. O'Keeffe

Frances Brooke

J. O'Keeffe
Ballad Opera 1 act

Comic Opera 2 acts

Comic Opera 3 acts

Comic Opera 3 acts

Ballad Opera 2 acts

Comic Opera 2 acts

Comic Opera 2 acts

Comic Opera 3 acts
London

Premiere

Drury Lane

Feb. 1775

Drury Lane Aug. 1731

Drury Lane Oct. 1768

Covent Garden Nov. 1775

Covent Garden

Dec. 1762

Covent Garden

Nov. 1783

LTH*

Sept. 1781

Covent Garden Dec. 1782

Covent Garden Nov. 1782 
The Padlock [see above]

April 1796

July 1797

Jan. 1798

[2nd perf.

Feb. 1798]

March 1798

[add. perfs.

in March \&

June]

March, 1798

Apr. 1798

June 1798

[2nd perf.

in June]

June 1798

July 1798

Aug. 1798

Sept. 1798

Oct. 1798
The Poor Soldier [see above]

Richard Cœur de Lion

No Song No Supper

Duenna [see above]

The Return

Rosina [see above]

Abroad and at Home

The Romp

[reduced version of

Love In The City]

Robinson Crusoe

My Grandmother and Other Fairies

The Waterman
A. Grétry adapted by T. Linley Sr.

S. Storace

Prince Hoare

John Burgoyne

unknown

W. Shield

J.G. Holman

Pasticcio compiled by C. Dibdin

I. Bickerstaff

T. Linley

R. Sheridan

S. Storace

Prince Hoare

C. Dibdin

C. Dibdin

R. Sheridan
"Comic Opera"

3 acts

"Musical

Entertainment"

Comic Opera 3 acts

Comic Opera

2 acts

Pantomime

Comic Opera 2 acts

Comic Opera

$$
2 \text { acts }
$$

Drury Lane

Oct. 1786

Drury Lane

Apr. 1790

Covent Garden

Nov. 1796

Dublin 1771

LTH* Nov. 1781

Drury Lane

1781

LTH*

Dec. 1793

LTH*

Aug. 1774 
Jan. 1800

[rescheduled

to a later date]

Jan. 1800

[2nd. perf.

Feb.]

Mar. 1800

Sept. 1800

\section{Inkle and Yarico}

Robinson Crusoe [see above]

The Ladies Frolic
S. Arnold

G. Colman, Younger

J. Love

Bates, Arne, etc.

G. Colman, Younger

\section{S. Arnold}

\section{Comic Opera}

3 acts

LTH*

Aug. 1787

\author{
The Mountaineers \\ The Mountaineers
}

\author{
Ballad Opera \\ 2 acts \\ Comic Opera \\ 3 acts \\ Drury Lane \\ May, 1770 \\ LTH* $^{*}$ \\ Aug. 1793 \\ *Little Theatre in the Haymarket
}

$†$ This chart is based on information contained in advertisements which appeared in Halifax newspapers. There is no proof that all listed works were actually presented, but newspapers did publish cancellation or postponement notices when works could not be performed as advertised. An extensive list of theatrical notices is in Oland (1966). 


\section{NOTES}

1. The following sources contain information about the musical and theatrical life of Halifax during this period: Fergusson 1950; Blakeley 1951; Oland 1966; McGee 1969; Bains 1980.

2. Gentlemen's Magazine, February 1750, p. 72; letter dated "Halifax in Nova Scotia, Dec. 7, 1749."

3. Nova Scotia Chronicle and Weekly Advertiser, 13-20 March 1770 , p. 95. [p. 2].

4. Halifax Gazette, 17 August 1754, [p. 2]; and 24 August 1754,

5. Halifax Gazette, 3 October 1765, [p. 2].

6. Nova Scotia Chronicle and Weekly Advertiser, 20-27 June 1769, p. 207.

7. Nova Scotia Chronicle, 31 July-7 August 1770, p. 255.

8. Royal Gazette and Nova Scotia Advertiser, 20 December 1791, [p. 4].

9. Halifax Gazette, 21 May 1761, [p. 2].

10. Nova Scotia Gazette and Weekly Chronicle, 8 September 1772 , [p. 3].

11. J. D. Hazen Collection, Shelf 88, Box 2, Folder 3, No. 7, New Brunswick Museum, St. John.

12. Letter from Jonathan Belcher to Secretary Pownall dated "Halifax, Nova Scotia, 4th January 1761" (Halifax: Public Archives of Nova Scotia).

13. For a more complete description of efforts to obtain an organ for St. Paul's see McGee 1969: 377-79.

14. St. Paul's Vestry Report of 24 July 1770 censured the clerk and organist for their choices of complicated music. The report is quoted in Kallmann 1969: 41.

15. Royal Gazette and Nova Scotia Advertiser, 26 May 1789, [p. 3].

16. Nova Scotia Chronicle and Weekly Advertiser, 12-19 September, 1769, p. 303.

17. The article quotes the contents of the bill sent to Wolfe.

18. Nova Scotia Gazette and Weekly Chronicle, 16 January 1781, p. 3.

19. Nova Scotian, 28 August 1828, p. 282.

20. Royal Gazette, 8 September 1802.

21. The Letterbooks of Prince Edward, Duke of Kent from September 1794 to May 1800, Royal Archives ADD. 7/57-698, no. 202, 27 October 1795. Quoted with the gracious permission of Her Majesty the Queen.

22. Nova Scotia Chronicle, 16-23 January 1770, pp. 30-31.

23. Nova Scotia Gazette and Weekly Chronicle, 6 January 1789, [p. 3]. 
24. For a more complete discussion of English opera of the eighteenth century see Fiske 1973.

25. The comic operas mentioned in this paper are discussed in more detail in Hall 1979.

\section{REFERENCES}

BAINS, Y. S.

1980: "The New Grand Theatre Halifax 1789-1814," The Nova Scotia Historical Quarterly, X/1, 1-21.

BLAKELEY, P.

1951: "Music in Nova Scotia 1605-1867," Dalhousie Review, XXXI/2, 94-101 \& XXXI/3, 223-30.

FERGUSSON, C. B.

1950: "The Rise of the Theatre at Halifax," Dalhousie Review, XXIX/3, 419-27.

FISKE, R.

1973: English Theatre Music in the Eighteenth Century. London: Oxford University Press.

HALL, S. L.

1979: "English Dialogue Opera." Ph.D. dissertation, University of Toronto.

JEFFERY, R. W., ed.

1907: Dyott's Diary. London: Constable.

KALLMANN, $\mathrm{H}$.

1969: A History of Music in Canada 1534-1914. Toronto: University of Toronto Press.

MacDONALD, J. S.

1912: "Memoir of Lieut.-Governor Michael Francklin, 1752-1782," Nova Scotia Historical Society Collections, XVI, 14-16.

McGEE, T. J.

1969: "Music in Halifax, 1749-1799" Dalhousie Review, XLIX/3, 377-87.

MOORSOM, W.

1830: Letters from Nova Scotia. London: Colburn and Bentley. OLAND, S. M.

1966: "Materials for a History of the Theatre in Early Halifax." M.A. thesis, Dalhousie University. 